\title{
Plasma exchange in systemic lupus erythematosus
}

\author{
H. F. PAR R Y \\ C. J. MORAN \\ M. L. SNAITH \\ J. D. M. RICHARDS \\ A. H. GOLDSTONE
}

From the Departments of Haematology and
Rheumatology, University College Hospital, London

\author{
L. J. NINEHAM \\ F. C. HAY \\ W. J. W. MORROW \\ I. M. ROITT
}

From the Department of Immunology, Middlesex Hospital, London

SUMMARY Eight out of 10 patients studied longitudinally received benefit from plasmapheresis. The patients were used as their own controls, being treated in a steady state as far as was possible. Levels of circulating complexes did not bear a close relationship with clinical results. On this evidence plasma exchange alone does not appear to represent an important part of the long-term management of patients with systemic lupus erythematosus but may well be of value in combination with other therapy.

Since the first reported attempts ${ }^{1}$ to perform therapeutic plasma exchanges on patients with hyperviscosity the technique has grown steadily, both in sophistication through the advent of double plastic blood-collecting bags, and more recently through cell-separators, and in the range of disorders treated. ${ }^{2-8}$

It is now widely accepted that the clinical manifestations of systemic lupus erythematosus (SLE) are mediated through immune complexes, ${ }^{9}$ and it has been shown that intensive plasma exchange can be an effective method of reducing circulating immune complexes ${ }^{68}$ and other plasma components. ${ }^{5} 10$ Previous studies have suggested that plasmapheresis can be useful therapeutically in patients with high levels of immune complexes. ${ }^{6} 8$ However, changes in disease activity might be accounted for by changes in drug therapy and the natural fluctuations of the disease itself.

SLE is a disease remarkable for its varied clinical presentation and for apparently spontaneous remissions and relapses. A controlled study of treatment with plasma exchange would obviously be ideal. We did not consider this feasible, however, in view of the probable need to match patients for organ involvement, with a relatively small number of patients available for study. Consequently the aims of this study were to stabilise other forms of therapy

\section{Accepted for publication 10 July 1979}

Correspondence to Dr M. L. Snaith, Department of Rheumatology and Rehabilitation, University College Hospital, Gower Street, London WC1E 6AU. as far as possible and to follow up the patients longitudinally in order to use them as their own controls, thus establishing as nearly as possible that any change in disease activity was due to plasmapheresis alone. It was also hoped to establish whether plasmapheresis has a role in the treatment of acute exacerbations or is likely to be of benefit in the long-term treatment of SLE, and to assess whether the materials used in exchange for the plasma differ in their therapeutic effects.

\section{Patients and methods}

Clinical features of the patients are summarised in Table 1.

All patients complied with the American Rheumatism Association's preliminary criteria for the diagnosis of SLE. ${ }^{11}$ A heterogeneous group of 10 female patients with SLE received a total of 13 courses of plasmapheresis. Patient 1 had received 2 short courses of plasmapheresis 12 months previously resulting in transient clinical benefit, since when she had fully relapsed to her preplasmapheresis state. Two patients were treated acutely, being too ill to be followed up over a long period, and 8 patients were studied according to the following protocol.

Before plasmapheresis each patient's treatment was progressively stabilised, corticosteroids in particular being reduced to an acceptable minimum. During a final run-in period of at least 6 weeks the drugs were maintained at a constant dosage. When possible, the patient was admitted to hospital for a 5-day period of bedrest, discharged, then readmitted 
Table 1 Patients: clinical features and previous treatment

\begin{tabular}{|c|c|c|c|}
\hline $\begin{array}{l}\text { Patient } \\
\text { No. }\end{array}$ & Age & Major clinical features & Base-line treatment \\
\hline $1^{*}$ & 56 & $\begin{array}{l}\text { Polyarthritis, skin rash, cerebral } \\
\text { symptoms (abnormal EEG } \\
\text { and oxygen scan) }\end{array}$ & $\begin{array}{r}\text { Prednisolone } 7 \mathrm{mg} \\
\text { daily. Salicylates }\end{array}$ \\
\hline 2 & 32 & $\begin{array}{l}\text { Polyarthralgia, skin rash, } \\
\text { alopecia, Raynaud's } \\
\text { phenomenon }\end{array}$ & Salicylates \\
\hline 3 & 54 & Polyarthritis, thrombocytopenia & $\begin{array}{c}\text { Prednisolone } 10 \mathrm{mg} \\
\text { daily. Salicylates }\end{array}$ \\
\hline 4 & 26 & $\begin{array}{l}\text { Polyarthralgia, skin rash, } \\
\text { (C2 deficiency) }\end{array}$ & $\begin{array}{l}\text { Prednisolone } 5 \mathrm{mg} \\
\text { daily }\end{array}$ \\
\hline 5 & 39 & $\begin{array}{l}\text { Skin rash, nephritis, (proteinuria } \\
8 \mathrm{~g} / 24 \text { hours) }\end{array}$ & $\begin{array}{l}\text { Prednisolone } 10 \mathrm{mg} \\
\text { daily }\end{array}$ \\
\hline 6 & 33 & $\begin{array}{l}\text { Skin rash, nephritis, (proteinuria } \\
12 \mathrm{~g} / 24 \text { hours) }\end{array}$ & $\begin{array}{l}\text { Prednisolone } 10 \mathrm{mg} \\
\text { and azathioprine } \\
150 \mathrm{mg} \text { daily }\end{array}$ \\
\hline 7 & 38 & $\begin{array}{l}\text { Skin rash, cerebral symptoms } \\
\text { (abnormal EEG and oxygen } \\
\text { scan) }\end{array}$ & Prednisolone $10 \mathrm{mg}$ \\
\hline 8 & 25 & $\begin{array}{l}\text { Raynaud's phenomenon, } \\
\text { cutaneous vasculitis, } \\
\text { gangrenous toes }\end{array}$ & $\begin{array}{l}\text { Prednisolone } 10 \mathrm{mg} \\
\text { daily }\end{array}$ \\
\hline 9 & 26 & $\begin{array}{l}\text { Polyarthralgia and skin rash. } \\
\text { Admitted with acute } \\
\text { fulminating SLE involving } \\
\text { cerebral, cardiac and } \\
\text { respiratory disease, alopecia, } \\
\text { cutaneous vasculitis and renal } \\
\text { failure }\end{array}$ & $\begin{array}{l}\text { (Previously } \\
\text { Prednisolone } \\
10-20 \mathrm{mg} \text { daily). } \\
\text { Initially to } 40 \mathrm{mg} \\
\text { then } 1 \mathrm{~g} \text { daily } \times 3\end{array}$ \\
\hline 10 & 48 & $\begin{array}{l}\text { Polyarthralgia, cerebral } \\
\text { symptoms, hemiparesis. } \\
\text { thrombocytopenia }\end{array}$ & $\begin{array}{l}\text { Initially, } \\
\text { methylpredni- } \\
\text { solone } 1 \mathrm{~g} \text { daily } \\
\times 3\end{array}$ \\
\hline
\end{tabular}

*See text for previous treatment.

when it had become apparent that no appreciable change in the clinical status of the patient had occurred on bedrest alone. At each clinic visit the following observations were made: (1) the patient's feeling of well-being on a $10 \mathrm{~cm}$ horizontal visual analogue scale; (2) duration of morning stiffness in hours; (3) the existence and severity of hair loss, skin rash, and cutaneous vasculitis (grades 0 to +++ ); (4) existence and severity of signs and symptoms of central nervous system involvement (graded, as far as feasible, 0 to +++$)$; (5) the time taken to walk $100 \mathrm{ft}$ $(30 \mathrm{~m}) ;(6)$ grip strength using a bag inflated to $30 \mathrm{mmHg}$ attached to a sphygmomanometer; (7) articular index for tender joints. ${ }^{12}$

The following laboratory assessments were made as far as possible at each visit: full blood count, platelets and ESR, immunoglobulins, urine analysis for protein and casts; serum immune complexes, serum double stranded DNA binding capacity, ${ }^{13}$ and complement activity. ${ }^{14}$ At intervals, where relevant, creatinine clearance and urinary protein excretion were measured. Electroencephalograms (EEG), electrocardiograms (ECG), and pulmonary function testing were performed when appropriate. Oxygen brain scans ${ }^{15}$ were also arranged with the kind co-operation of Dr T. Jones of the Cyclotron Unit, Hammersmith Hospital.

\section{PLASMA PHERESIS}

Ten exchanges of approximately 31 each were performed over a period of 12 days. The plasma was exchanged with an equivalent volume of either fresh frozen plasma or plasma protein fraction. Plasmapheresis was performed with a Haemonetics Model 30 blood processor used with a flow rate of $30-50 \mathrm{ml} /$ min, citrate being used as an anticoagulant. Care was taken to limit hypovolaemia to a minimum. Exchange was performed either through a venovenous peripheral line or a centrally placed subclavian catheter when peripheral veins were inadequate.

\section{CIRCULATING IMMUNE COMPLEXES (CIC)}

The C1q solid phase radioassay was performed as described previously. ${ }^{16-18} \mathrm{Clq}$ was coated on to the surface of polystyrene tubes. Immune complexes were bound to the solid phase $\mathrm{Clq}$ and then detected by the addition of radiolabelled, immunoabsorbent purified anti-IgG, confirming the immunoglobulin nature of the material bound to the C1q.

CIC were also determined by precipitation with polythylene glycol by a modification ${ }^{19}$ of the method of Creighton et al. ${ }^{20}$ After washing, precipitates were redissolved and the IgG and IgM were quantitated by single radial immunodiffusion.

\section{STATISTICAL ANALYSIS}

Patients were used as their own controls. Change in their clinical state was assessed by the MannWhitney $U$ test comparing the mean of preplasmapheresis data with postplasmapheresis data in each individual. Immune complex data were assessed for the group as a whole by the paired $t$ test.

\section{Results}

There was no change in the clinical status of patients during the bed rest period (6 patients). However, in some patients there was a reduction in levels of circulating immune complexes, which returned to pretreatment levels after the patient became mobile once more.

The clinical benefits of plasmapheresis are summarised in Table 2. Appreciable changes in many parameters could be seen for several days after plasmapheresis, but data in the table are confined to those observed at intervals of more than 1 week. Of 11 plasmaphereses on patients Nos. 1-8 performed according to our protocol 9 resulted in statistically significant $(\mathrm{P}<0.05)$ improvement in at least 1 of the clinical parameters measured. The duration of some degree of statistically significant benefit lasted from 1 week to over a year, with a mean of 11 weeks. In patient No. 8 no improvement occurred, and patient No. 4 actually deteriorated but returned to her 
Table 2 Results of plasmapheresis in 10 patients, clinical data: duration of improvement following treatment (in weeks)

\begin{tabular}{|c|c|c|c|c|c|c|c|c|c|c|c|c|c|}
\hline \multirow{2}{*}{$\begin{array}{l}\text { Patient } \\
\text { Treatment }\end{array}$} & \multirow{2}{*}{$\begin{array}{l}\text { Visual } \\
\text { analogue }\end{array}$} & \multirow{2}{*}{$\begin{array}{l}\text { Articular } \\
\text { index }\end{array}$} & \multirow{2}{*}{$\begin{array}{l}\text { Raynaud's } \\
\text { phenomenon }\end{array}$} & \multirow{2}{*}{$\begin{array}{l}\text { Skin } \\
\text { rash }\end{array}$} & \multirow{2}{*}{$\begin{array}{l}\text { Hair } \\
\text { loss }\end{array}$} & \multirow{2}{*}{$\begin{array}{l}\text { Walking } \\
\text { time }\end{array}$} & \multirow{2}{*}{$\begin{array}{l}\text { Grip } \\
\text { strength }\end{array}$} & \multirow{2}{*}{$\begin{array}{l}\text { CNS } \\
\text { features }\end{array}$} & \multirow[t]{2}{*}{$E S R$} & \multicolumn{3}{|c|}{$\begin{array}{l}\text { Immune complexes Plate- } \\
\text {-lets }\end{array}$} & \multirow[t]{2}{*}{ Renal function } \\
\hline & & & & & & & & & & $C I q$ & $P E G$ & & \\
\hline $1 \mathrm{Bed}$ & - & - & & - & & - & - & - & - & - & - & & \\
\hline PPF & $2(2)$ & $-(7)$ & & -(4) & & - & $-(5)$ & -2 & 一 & 2 & & & \\
\hline FFP & $12(12)$ & $7(12)$ & & $6(10)$ & & - & -(4) & $12(12)$ & - & $1(\uparrow 5)$ & $\mathrm{ns}(\uparrow 5)$ & & \\
\hline 2 Bed & - & - & - & - & - & & - & & - & $\mathrm{n} / \mathrm{a}$ & $\mathrm{n} / \mathrm{a}$ & & \\
\hline PPF & $3(4)$ & $4(4)$ & $-(4)$ & $-(4)$ & -(4) & $-(3)$ & & & 1 & 1 & - & & \\
\hline FFP & $12(16)$ & $8(16)$ & -(1) & $2(6)$ & & $2(12)$ & & & 4 & 1 & $\uparrow 2$ & & \\
\hline $3 \mathrm{Bed}$ & - & - & & & & - & - & & - & - & & - & \\
\hline PPF & - & -(3) & & & & $-(10)$ & $-(2)$ & & - & 1 & & 10 & \\
\hline FFP & $2(6)$ & -(4) & & & & $8(8)$ & $3(3)$ & & - & - & & & \\
\hline $4 \mathrm{Bed}$ & - & & & & - & & & & & & & & \\
\hline PPF & - & & & $1 \uparrow$ & - & & & & & & & & \\
\hline $5 \mathrm{Bed}$ & & & & & & & & & 3 & 1 & & & 24 hour proteinuria \\
\hline PPF & & & & & & & & & 3 & 1 & & & $>52$ weeks \\
\hline 6 FFP & & & & $>1 \mathrm{yr}$ & & & & & & & & & $\begin{array}{l}\text { Creatinine clearance } \\
>52 \text { weeks }\end{array}$ \\
\hline $7 \mathrm{Bed}$ & - & & & - & & & & - & & & & & \\
\hline PPF & 10 & & & 12 & & & & 12 & & & & & \\
\hline
\end{tabular}

8 PPF

$93 \mathrm{G}$

Steroids Gradual recovery following plasmapheresis. See text PPF

$103 \mathrm{G}$

Steroids No effect on clinical parameters over 14 days

Gradual recovery following plasmapheresis. See text

PPF CNS features unchanged. See text

No effect on clincial parameters over 14 days Platelets returned to normal. Sie text

Key: 1 = Number of weeks up to which there was a statistically significant difference from base-line. (1) $=$ Number of weeks to return to pretreatment baseline value. $-=$ No significant difference from baseline. Blank $=$ Not applicable. $n / a=$ Not available.

pretreatment state within 3 days of ending plasmapheresis. This latter patient had homozygous $\mathrm{C} 2$ deficiency. Subjectively all but patients Nos. 4 and 8 claimed substantial benefit. A further 2 patients, Nos. 9 and 10, were admitted with fulminant SLE, and thus were of necessity treated in a nonsteady state. Of these 2, patient No. 9 recovered fully after plasmapheresis while the other, patient No. 10, obtained little benefit, although she had only 5 exchanges because of difficulties of vascular access. She had severe cerebral involvement with an established hemiparesis.

Three patients (Nos. 1, 2, 3) were treated initially with plasma protein fraction (PPF) and subsequently with fresh frozen plasma (FFP) after they had fully returned to their pretreatment level of disease activity. Benefits from plasmapheresis with FFP lasted longer in all 3 patients.

Apart from the patient (No. 4) with homozygous $\mathrm{C} 2$ deficiency none of the patients suffered any worsening of the disease as a result of plasmapheresis, and the procedure itself was well tolerated. Occasional feelings of faintness and mild citrate toxicity, which was rectified easily, were the only problems apart form 1 patient (No. 7) whose central venous catheter became infected and had to be resited.

The clinical pattern of organ involvement (renal, arthralgia, etc.,) appeared to have little relation to the outcome following plasmapheresis.

Patient No. 6 was the only patient who was also being treated with azathioprine. Her benefit was considerably longer in duration than the other patients' (52 weeks).

The reduction in levels of circulating immune complexes for the whole group of patients was highly significant immediately after plasmapheresis $(P<0.001)$ and was still significant 1 week after finishing treatment $(P<0.05)$. The difference had ceased to be significant after 2 weeks $(0.975$ $<P>0.96)$. The mean percentage drop in levels of circulating immune complexes immediately after plasmapheresis was $52 \cdot 2 \%$ and after 1 week was $18 \cdot 2 \%$.

\section{Discussion}

From the above data it is clear that a temporary beneficial response to plasmapheresis can usually be obtained. It is not clear whether longer lasting remissions may be attributed to the treatment or to natural fluctuations in the disease itself. Our data (to be published elsewhere) also confirm that plasmapheresis can be an effective means of reducing circulating immune complexes, complement, antibodies, and other plasma components at least temporarily, although it appears to be more effective in some patients than others. We did not find that initial levels of circulating immune complexes were related to the success of the procedure, contrary to the findings of Verrier-Jones and co-workers. ${ }^{6}$ Indeed, good improvement was observed in patient 
No. 5 who had normal levels of complexes, suggesting that other factors such as alteration in the qualitative properties of circulating immune complexes and removal of inflammatory mediators may be important. Although bed rest was not shown to affect the course of the disease, the change in levels of circulating immune complexes accompanying it is interesting. The reasons for this are not clear but may represent a change in vascular permeability as much as an alteration in production of immune complexes. This phenomenon also suggests that mechanisms other than mechanical removal of plasma components may be involved. It has been suggested that exposure of blood to plastic surfaces during dialysis may result in lowering of circulating immune complexes, and this mechanism may also have some importance during plasmapheresis.

Three patients were subjected to plasmapheresis, on different occasions, with PPF and FFP. It has been shown that complement is involved in the clearance and solubility of immune complexes, ${ }^{21}$ suggesting that exchange with FFP may be more beneficial than with PPF. Against this, complement also acts as a mediator of inflammation, and its addition may exacerbate the disease. Our evidence is insufficient to make a case for either replacement fluid, but length of remission was slightly longer after the FFP exchanges.

We found that DNA binding was considerably reduced. In view of the possibility that complexes observed in tissues may be formed locally rather than deposited from the circulation, a lowering of antibody levels may influence this complex formation.

The mechanism of benefit of plasmapheresis is probably complex. The physical removal of immune complexes and other inflammatory mediators ${ }^{6} 8$ presumably has an effect. It is also possible that plasmapheresis may improve the ability of the reticuloendothelial system to remove circulating immune complexes. Antibody affinity may affect the pathogenicity of immune complexes, ${ }^{22}$ and removal of antibody might influence this. It has also been suggested that plasmapheresis may exacerbate the illness through stimulating antibody production, 523 though we have no evidence for this or for a sustained influence on the factors contributing to immune complex formation and deposition.

The major role of plasmapheresis would seem to be in the control of the acute exacerbation, and it is less likely to be of practical value in chronic disease, though it may be useful when other forms of therapy have failed. It may be relevant that feedback control may be stimulated by reduction in antibody, at which phase the use of cytotoxic drugs could be especially relevant. There may be a place for combining plasma exchange with other treatment such as cytotoxic drugs, high dose pulses of steroids, antilymphocyte globulin, or levamisole in the initial control of the disease. Such forms of treatment might best be tested with multicentre controlled trials.

The authors are especially grateful to the Sir Jules Thorn Foundation for the provision of Fellowships (H.F.P. and W.J.W.M.) and to the Medical Research Council for financial support to the Department of Immunology, Middlesex Hospital.

The authors would also like to thank Ms Alison Rae for technical assistance.

\section{References}

1 Solomon A, Fahey J L. Plasmapheresis therapy in macroglobulinemia. Ann Intern Med 1963; 58: 789-800.

2 Kovacs L, Keseru T L, Imre G. Plasmapheresis in Rh isoimmunisation. Lancet 1973; i: 1253.

3 Hersey P, Ibister J, Edwards A, et al. Antibody-dependent cell-mediated cytotoxicity against melanoma cells induced by plasmapheresis. Lancet 1976 ; i: 825-8.

4 Lancet 1976; i: 1113.

5 Lockwood C M, Rees A J, Pearson T A, et al. Immunosuppression and plasma-exchange in the treatment of Goodpasture's syndrome. Lancet 1976; i: 711-5.

6 Verrier-Jones J, Bucknall R C, Cumming R H, et al. Plasmapheresis in the management of acute systemic lupus erythematosus. Lancet 1976; i: 709-11.

7 Laningham J E. Partial plasma exchange, and adjunct in therapy to complex clinical problems. Transfusion 1977; 17: 547-54.

${ }^{8}$ Lockwood C M, Pinching A J, Sweny P, et al. Plasmaexchange and immunosuppression in the treatment of fulminating immune complex crescentic nephritis. Lancet 1977; i: $63-7$.

9 Cochrane C G, Koffler D. Immune complex disease in experimental animals and man. Adv Immunol 1973; 16: 185-264.

10 Keller A J, Urbaniak S J. Intensive plasma exchange on the cell separator: effects on serum immunoglobulins and complement components. BrJ Haematol 1978; 38: 531-40.

11 Cohen A S, Reynolds W E, Franklin E C, et al. Preliminary criteria for the classification of systemic lupus erythematosus. Bull Rheum Dis 1971; 21 : 643-8.

12 Ritchie D M, Boyle J A, McIness $\mathrm{JV}^{\mathbf{V}} \mathrm{M}$, et al. Clinical studies with an articular index for the assessment of joint tenderness in patients with rheumatoid arthritis. $Q J \mathrm{Med}$ 1968; 37: 393-406.

13 Holihan J, Griffiths I D, Glass $\mathrm{D}^{-} \mathrm{N}$, et al. Human antiDNA antibody: reference standards for diagnosis and management of systemic lupus erythematosus. Ann Rheum Dis 1975 ; 34: 438-43.

14 Mayer M M. Complement and complement fixation. In: Kabat E A, Mayer M M, eds. Experimental Immunochemistry. 2nd ed. Springfield: Thomas, 1961: 133-240.

15 Pinching A J, Travers $\mathrm{R}^{-} \mathrm{L}$, Hughes $\mathrm{G}^{-} \mathrm{R} \mathrm{V}$, et al. Oxygen15 brain scanning for detection of cerebral involvement in systemic lupus erythematosus. Lancet 1978; i: 898-900.

16 Hay F C, Nineham L J, Roitt I M. Routine assay for the detection of immune complexes of known immunoglobulin class using solid phase C1q. Clin Exp Immunol $1976 ; 24: 396-400$.

17 Lambert $\mathrm{P}$ H, Dixon F J, Zubler R H, et al. A WHO collaborative study for the evaluation of eighteen methods for detecting immune-complexes in serum. $J$ Lab Clin Immunol 1978; 1 : 1-18. 
18 Hay F C, Nineham L J, Perumal R, et al. Intra-articular and circulating immune complexes and antiglobulins (IgG and IgM) in rheumatoid arthritis: correlation with clinical features. Ann Rheum Dis 1979; 38: 1-7.

19 Poulton T A, Crowther M E, Hay F C, et al. Immune complexes in ovarian cancer. Lancet 1978; ii: 72-3.

20 Creighton W D, Lambert P H, Miescher P A. Detection of antibodies and soluble antigen-antibody complexes by precipitation with polythylene glycol. J Immunol 1973; 111: 1219-27.
21 Czop J, Nussenzweig V. Studies on the mechanism of solubilization of immune precipitates by serum. $J$ Exp Med 1976; 143: 615-30.

22 Alpers J H, Steward M, Soothill J F. Differences in immune elimination in inbred mice: the role of low affinity antibody. Clin Exp Immunol 1972; 12: 121-32.

23 Bystryn J C, Schenken I, Uhr J W. A model for the regulation of antibody synthesis by serum antibody. In: Amos B, ed. Progress in Immunology 1. New York: Academic Press, 1972: 627-36. 